UDC 81' $1: 81$ '2/44

DOI https://doi.org/10.32838/2663-6069/2020.1-3/09

Slabouz $\boldsymbol{V} . \boldsymbol{V}$.

Donbas State Pedagogical University

Nikitina N.P.

Donbas State Pedagogical University

\title{
BASIC METHODOLOGICAL PRINCIPLES OF COGNITIVE STUDIES IN DOMESTIC LINGUISTICS
}

\begin{abstract}
The article presents the material on basic methodological principles of cognitive studies in domestic general linguistics. The relevance of the study is explained by the fact that cognitive linguistics is viewed as a new paradigm of scientific knowledge and consequently is characterized by various theoretical ideas. The cognitivism development in our country and abroad are rather divergent and have become quite independent. There exists some confusion in determining the philosophical and theoretical foundations of many linguistic studies, consequently, there is the need to present a simplifies and free interpretation of rather complex concepts of cognitive linguistics. The main objective of the paper is to systematize the basic theoretical and methodological guidelines of the domestic version of cognitive linguistics, which differs from the foreign paradigms of knowledge not only in terms of prerequisites and assumptions, but also in the subject areas of its interests and approaches to the problems posed and how to solve them, as well as to assign the eight main principles of cognitive studies in domestic linguistics, and to analyze them. The eight basic methodological principles of cognitive studies in domestic general linguistics are represented and substantiated. The analyzed principles and methodologically important provisions determining modern cognitive studies of language allow concluding that domestic cognitive linguistics is a formed direction of linguistic thought, fundamentally different from foreign analogues. Domestic cognitive linguistics occupies a special place in the conceptual space of cognitive linguistics and cognitive science as a whole. Cognitive linguistics inherits the acquisitions of all linguistic paradigms that have existed before it, and develops along with philosophy and psychology the existing problems of the connections between language and thinking, but treats them in categories such as knowledge, language varieties of knowledge, language modes of knowledge representation, procedures for using knowledge, mental structures.
\end{abstract}

Key words: domestic general linguistics, cognitive linguistics, cognitive studies, cognitology, cognitologist, methodological principles, paradigm of scientific knowledge.

The problem setting. The rapid development of cognitive linguistics is considered a characteristic feature of modern world linguistics. It is enough to note the fact that in almost all the leading countries of Europe, as well as in America, China and Russia, there are national associations that unite linguistscognitologists in their ranks. In parallel with this, the number of representative international congresses devoted to the problems of cognitive linguistics is growing, special journals are published. All of the above indicates that over the past 20 years, cognitive studies of language have taken a definite place in the general system of scientific views on language and methods of studying it, having formed their own theoretical and methodological guidelines and a conceptual and terminological apparatus $[4 ; 10 ; 13]$. It is believed that two key moments in the development of science have created the prerequisites for the formation of the cognitive direction in linguistics: 1) awareness of the need to study work of human consciousness systematically and to understand that only language provides the only reliable access to consciousness; 2) understanding of the need to study processes of not only theoretical but also everyday cognition, as well as the need to study the influence of human consciousness on decision-making and the implementation of various activities, including language $[4$, p. 20]. The general attitude of cognitologists is expressed by G. Fauconnier, saying that "linguistics becomes something more than a self-sufficient limited area of language learning; it contributes to the discovery and explanation of the general aspects of human cognition" [31, p. 124].

Cognitive linguistics is considered to be a new post-generative paradigm of scientific knowledge, 
which is formed under the influence of cognitive science and characterized, like all cognitive science, by a sufficient variety of theoretical positions. As a result, the lines of cognitivism development in our country and abroad have diverged to a large extent and have turned out to be quite independent. In this regard, there is confusion in determining the general philosophical and theoretical foundations of many interesting and significant linguistic studies, juggling them with terms related to methods of analysis of the language material, and a simplified and free interpretation of many rather complex concepts of linguistics. All of the above determines the relevance of our study.

The analysis of recent studies and publications. The following scientists and scholars (mainly the American ones), such as A. Cienki, G. Fauconnier, Ch. J. Fillmore, R. Jackendoff, G. Lakoff, R. W. Langacker, B. RudzkaOstyn, L. Talmy, J. H. Taylor [28; 32-36; 38; 40; 41], are the representatives of the cognitive approach in linguistics. The work by R. Jackendoff "Semantics and Cognition" is mostly famous [33]. In this work, the scientist substantiates the connection of semantics with psychology. The same problem is studied by the Ukrainian linguist A. Zelenko [8]. U. Apresian, N. Boldyrev, O. Vorobiova, S. Zhabotinskaia, V. Konokeko, E. Kubriakova, A. Martyniuk, V. Maslova, M. Poliuzhin, T. Radzievska, O. Selyvanova, H. Yavorska $[1-7 ; 9 ; 11-15 ; 17 ; 18 ; 21 ; 22 ; 25 ; 29]$ deal with the problems of cognitive linguistics in domestic linguistics.

The purpose of the article is to systematize the basic theoretical and methodological guidelines of the domestic version of cognitive linguistics, which differs from the foreign paradigms of knowledge not only in terms of prerequisites and assumptions, but also in the subject areas of its interests and approaches to the problems posed and how to solve them, as well as to assign the eight main principles of cognitive studies in domestic linguistics, and to analyse them.

The results and discussions. Although the domestic version of cognitive linguistics, called the cognitive-discursive paradigm, arose initially in the depths of classical cognitive science, which means that it received impulses of its development abroad, it very soon outgrew the limits of narrow cognitivism. This happened to a greater extent since the cognitive-discursive paradigm, as E. Kubriakova repeatedly emphasizes in her works, inherits, along with the general attitudes of cognitivism, the tradition of domestic linguistics and psychology, in many respects continues the ideas of the onomasiological direction when analysing language phenomena
$[12 ; 15]$. Cognitive linguistics proceeds from the inseparability of the processes of cognition and communication in the real functioning of language, from the deep interdependence and consistency of these processes, and, accordingly, the functions correlating with them [12, p. 43]. The basis of the cognitive approach to language is understanding language as a means of forming and expressing thoughts, storing and organizing knowledge in the human mind, and sharing knowledge. This understanding indicates the unity of cognitivereflective (cognitive) and communicative functions of language, which L. Vygotskyi regarded as "the unity of communication and generalization" and what gave rise to E. Kubriakova to determine the orienting function as the main one for language, despite the fact that the main efforts in the framework of cognitive linguistics are aimed at a deep and comprehensive study of the cognitive function of language in all its manifestations.

Thus, the principle of equality of the two basic functions of language (cognitive and communicative) can be considered as methodologically significant for domestic cognitive linguistics. It implies that when using language, both of these functions are invariably and constantly consistent, interacting with each other. Consequently, it becomes necessary to take into account the cognitive and discursive aspects of the being and functioning of a particularphenomenon when studying specific phenomena of language, i.e. the need to study any linguistic phenomenon, following the figurative expression by E. Kubriakova, "at the crossroads of cognition and communication" $[13$, p. 16]. The purpose of such an analysis is "the identification and detailed description of the structures of knowledge, opinions and assessments which are behind literally each language unit, category, form. With an emphasis on the cognitive component, it is being spoken of the content and meaning of linguistic phenomena; with an emphasis on the discursive one - of the means of supplying and distributing information on the "surface" of the units under consideration (from the smallest units - words - to the largest ones - discourse)" [14, p. 28].

The principle of multifactority when analysing each linguistic phenomenon is associated with identifying the role of this phenomenon while implementing the cognitive activity and carrying out the communicative activity, and therefore it is inextricably linked with the principle of systematicity, according to which the phenomenon under study should be described not only in its place respectively to the linguistic system itself, but also respectively 
to those more "high" systems, of which the language itself is a part.

The principle of interdisciplinarity involves accounting and summarizing the data obtained in the field of philosophy, cognitive psychology, psycholinguistics, logic, information theory, theory of cognition, physiology, neuroscience, etc. Studying language as one of the cognitive abilities of a human and an integral element of the human brain cannot but take into account the relationship of the phenomenon under study with perception, distribution of attention, memory, as well as how the conceptual system is organized in our consciousness. Herewith, according to N. Boldyrev's consideration, interdisciplinarity should be understood as using the data of other sciences rather than conducting one's own studies in other areas of knowledge, as under the modern conditions it is impossible to receive a complete picture of an object remaining within the framework of one scientific field [5, p. 13].

The principle of anthropocentricity is associated with studying a wide range of linguistic phenomena reflected in the linguistic consciousness of speakers or reflecting the presence of a speaker in an act of speech and establishing a system of his/her "coordinates" [26, p. 50-51]. In general terms, this principle can be formulated as follows: language is focused on a person in the framework of all his/her cognitive activities, in language a person is represented in all the variety of functions performed by him/ her. At the same time, it is necessary to highlight two mandatory role characteristics of a person's manifestation in language - the role of the cognizing subject and the role of the speaking subject. In accordance with this, a significant role in the formation of the meanings of linguistic units and expressions belongs to a person as a subject of cognition, as a carrier of certain knowledge and experience. As N. Boldyrev emphasizes, "it is a person, as a person cognizing and speaking a certain language, who forms meanings and does not reproduce them in a ready-made way (the principle of creativity of speech thinking), and a specifically speaking person consciously chooses language means of expression to describe a particular situation [5, p. 13]. Taking into account the principle of anthropocentricity in cognitive studies of language allows scientifically proving and showing the close connection of the entire system of language with cognitive activities of a person. It is important to consider that cognitive activity itself as a systemic, conscious, and purposeful activity is not a simple copy of reality, i. e. reflective, it is characterized by the ability to generalize, has a multi-level character and is of representative nature. This allows concluding that a person does not reflect the world in language, but carries out conceptual refraction of knowledge about it [16]. Thus, in the process of forming the meaning of a linguistic sign, a person turns to both linguistic knowledge and non-linguistic knowledge (knowledge about the world).

The principle of the multiple-level system of analysis of semantics of linguistic units requires studying the meaning of linguistic units in the context of various cognitive structures. The arguments in favour of the fact that the lexical meaning, for example, is more determined by its cognitive basis are found and proved in the works by the well-known domestic (E. Kubriakova, N. Boldyrev) and foreign (G. Fauconnier, Ch. J. Fillmore, G. Lakoff) scientists. In accordance with the precepts of cognitive linguistics, the meanings of words in the system of language turn out to be correlated not so much with paradigmatic and syntagmatic contexts as with cognitive contexts that N. Boldyrev understands "as cognitive structures or blocks of knowledge that stand behind meanings and provide their understanding" $[4$, p. 26]. The decisive role of cognitive contexts in the process of understanding linguistic units and expressions supposes involving both linguistic and encyclopaedic knowledge in the linguistic analysis, which gives a multilevel character to the semantic theory. In this regard, the central place in the semantic theory the cognitive processes of conceptualization and categorization associated with the formation of the conceptual system of a person as a system of knowledge about the world in the form of concepts and categories acquire. With their regard, semantics are not limited to the field of linguistic knowledge proper but is the result of a certain way of understanding the world based on the correlation of linguistic meanings with specific concepts and categories (the lexical meaning, for example, is, for example, is more determined by its cognitive basis). As $\mathrm{Ch}$. Sinha considers, the semantics of natural languages is rooted in the human ability to conceptualize [39]. Consequently, the meanings are analysed as cognitive structures included in the models of knowledge and opinion [4, p. 25], concrete conceptualizations or as "a concept captured by a sign" (E. Kubriakova's term).

The principle of the conceptual unity of language and speech implies their interpretation as a single object of analysis. This is explained by the dependence of language on the objective world, thinking processes and speech use in their unity and interconnection. This interpretation is also 
confirmed by the possibility of distinguishing the two modes of language: as a complex of categories existing in potentia, and as a continuously repeating process [2, p. 77]. A detailed argumentation of this principle is proposed by N. Boldyrev, based on the points of view of S. Katcnelson, V. Pavlov, E. Coșeriu. In particular, the scientist emphasizes the need to study the "interconnections of all the components of a linguistic sign that belong to it in language and speech" $[5$, p. 20]. In this case, the cognitive approach to language removes the question of the primacy of one or the other component in the antinomy "language-speech", which exists in speech activity. It allows simultaneously covering both speech and language. Relying on the principle under consideration, as well as on the principle of multilevel analysis allows removing the well-known contradiction between the meaning and semantics of language units.

From the point of view of cognitive linguistics, the meaning of a linguistic unit and the semantics conveyed by it in the process of speech-thinking activity form a certain continuum, reflecting the continuum of a person's knowledge of the world, which is not fixed once and for all. This fact leads to the absence of clear boundaries between the meanings of different words and their multifunctionality. According to N. Boldyrev, systemic linguistic meanings act as cognitive reference points in the semantic continuum, representing the corresponding concepts and around which certain semantic categories are formed, including concrete speech meanings as elements [3, p. 17]. From the above said, it follows that the problem of the correlation of the meaning and semantics appears as a problem of the relationship between the conceptual content that is represented by the linguistic meaning in the system of language and that part of the content of the concept that is conveyed by the speech semantics.

This involves taking into account the principle of distinguishing between conceptual and semantic levels. Their differentiation leads to the separation of the non-linguistic level of conceptual representation and the level of linguistic representation, which, in turn, ensures the existence of a conceptual picture of the world and a language picture of the world. The distinction between the levels considered is manifested in the independence of the concept from language, which confirms the fact of the nonverbal nature of thinking. As a result, only a part of the concepts receives language objectification, which gives reason to distinguish between verbalized and non-verbalized conceptual content, the concept as a mental representation that exists as a gestalt unit, not structured before its being verbalized, and its verbalized correlate. The differentiation of the conceptual and semantic levels is not absolute; it implies at the same time their close interaction. It manifests itself, in particular, in the fact that semantics has two directions of connections - towards the conceptual system and towards the language system and, thus, turns out to be some kind of "bridge" or "interface" connecting the language system with the conceptual one [41].

The distinguished principles determine the significance of cognitive research of the number of methodologically important provisions, the analysis of which is presented further. The provision on the dynamism and ontological nature of conceptualization allows considering conceptualization as a process and as a result of cognitive processing of information by a person. Thanks to conceptualization, a person cognizes the outer world and the inner world of man; it is a process by which our knowledge of the world is formed, organized, structured, and the results of this process are reflected to one degree or another in language. It is the latter position that is especially emphasized by linguists $[1 ; 3-5 ; 23 ; 27]$. Conceptualization is a two-sided process. On the one hand, it is associated with the comprehension of the essences of the external world, the internal world of man, as well as any possible worlds and the world of language. On the other hand, it leads to the formation of concepts about certain meaningful phenomena and entities, i.e. structures of knowledge. The conceptualization of the world by man is carried out in the course of activities, because "it is in the course of activities (in its broad sense) that the functioning of the perceptual system occurs, as well as the development of cognitive abilities, and the formation of knowledge structures" [20, p. 24]. Another essential property of conceptualization is its ontological nature. "The ontological nature of the object determines the possibility for many means of conceptualization, which are codified in a certain way in language", I. Ruzin notes [24, p. 49]. The scientist pays special attention to the fact that ontology does not specify the need for conceptualization, but only a set of possibilities. As a result, conceptualization is non-rigid and "in many cases inconsistent in nature: out of a number of possibilities, it is realized one in some case (in some region, at some level), in some the other" [24, p. 49]. The aforesaid allows assuming that at different language levels a part of possibilities and means of conceptualization, which are verbalized in these or those language units, is realized. 
Several other provisions important for cognitive studies in linguistics follow from this position. The provision on the dynamic and non-verbal nature of the concept gives reason to present the concept not as a static unit, but as a non-rigid structure which is constantly developing, reflecting the results of all the cognitive activity of a person. This, in turn, implies the need to take into account in studying linguistic conceptualization the provision on the existence of two hypostases of the existence of the concept - as a unit of knowledge and as a structure of knowledge expressed in linguistic forms.

The provision of the language system as a projection of the cognized by man and language as a part of the conceptual system. In accordance with this, natural language, firstly, acts as "a code for the system concepts" [19, p. 114], and thereby "symbolically fixes certain concepts of the conceptual system of the world", which, in turn, leads to the construction of "a certain concept about language itself $<\ldots>$ containing knowledge of its physical and grammatical characteristics" [19, p. 112]. Secondly, based on assimilation and with the building of the concept of the grammatical structure of language, the latter makes it possible, by manipulating verbal characters, to manipulate the concepts of the system. This means that it is possible to build new conceptual structures in the conceptual system that are "continually but indirectly - through other concepts and their structures - are correlated with the concepts that reflect the individual cognitive experience of the person" $[19$, p. 114]. Thus, there arises a special type of concepts built with the help of language and related, according to R. Pavilenis, rather, to the possible than to the real experience of the person. Such a dual role of language in creating a conceptual system leads to the fact that language is "woven" into the conceptual system and serves to further structure and symbolic presentation of the content of certain conceptual systems.

Conclusions. The analysed principles and methodologically important provisions determining modern cognitive studies of language allow concluding that domestic cognitive linguistics is a formed direction oflinguistic thought, fundamentally different fromforeign analogues. Domestic cognitive linguistics occupies a special place in the conceptual space of cognitive linguistics and cognitive science as a whole. Cognitive linguistics inherits the acquisitions of all linguistic paradigms that have existed before it, and develops along with philosophy and psychology the existing problems of the connections between language and thinking, but treats them in categories such as knowledge, language varieties of knowledge, language modes of knowledge representation, procedures for using knowledge, mental structures. Cognitive linguistics emphasizes that a considerable part of a person's cognitive ability is his/ her language ability.

\section{References:}

1. Апресян Ю. Д. Образ человека по данным языка: попытка системного описания. Bonpocbl языкознания. 1995. № 1. С. 37-67.

2. Бодуэн де Куртенэ И. А. Избранные труды по общему языкознанию. Москва : Издательство АН CCCP, 1963. T. $1.384 \mathrm{c}$.

3. Болдырев Н. Н. Значение и смысл с когнитивной точки зрения и проблема многозначности. Когнитивная семантика: материалы 2-й междунар. школы-семинара по когнитивной лингвистике. Тамбов, 2000. Ч. І. С. $11-17$.

4. Болдырев Н. Н. Концептуальное пространство когнитивной лингвистики. Bопросы когнитивной лингвистики. 2004. № 1. С. 18-36.

5. Болдырев Н. Н. Принципы и методы когнитивных исследований языка. Принципы и методы когнитивных исследований языка : сб. науч. тр. Тамбов, 2008. С. 11-29.

6. Воробьева О. П. Концептология в Украине: обзор проблематики. Лингвоконщептология: перспективные направления: монография. Луганск : Изд-во ГУ «ЛНУ имени Т. Шевченко», 2013. С. 221-239.

7. Жаботинская С. А. Лингвокогнитивный подход к анализу номинативных процессов. Вісник Харківського наиіонального університету ім. В. Н. Каразіна. 2010. № 928. С. 6-20.

8. Зеленько А. С. Загальне мовознавство. Історія лінгвістичних учень. Аспекти, методи, прийоми та процедури вивчення мови : посібник. Вид. 2-ге, перероб. Луганськ : Альма-матер, 2002. 283 с.

9. Кононенко В. І. Концептологія в лінгвістичному аспекті. Мовознавство. 2006. № 2-3. С. 111-117.

10. Кравченко А. В. Когнитивная лингвистика сегодня: интеграционные процессы и проблема метода. Вопросы когнитивной лингвистики. 2004. № 1. С. 37-52.

11. Кубрякова Е. С. В поисках сущности языка. Международный конгресс по когнитивной лингвистике : сб. материалов. Тамбов, 2008. С. 43-47.

12. Кубрякова Е. С. В поисках сущности языка: вместо введения. Когнитивные исследования языка. Конщептуализация мира в языке : коллективная монография. Москва ; Тамбов, 2009. Вып. IV. С. 11-24. 
13. Кубрякова Е. С. Об установках когнитивной науки и актуальных проблемах когнитивной лингвистики. Вопросы когнитивной лингвистики. 2004. № 1. С. 6-17.

14. Кубрякова Е. С. Что может дать когнитивная лингвистика исследованию сознания и разума человека. Международный конгресс по когнитивной лингвистике : сб. материалов. Тамбов, 2006. С. $28-31$.

15. Кубрякова Е. С. Язык и знание : на пути получения знаний о языке. Части речи с когнитивной точки зрения. Роль языка в познании мира. Москва : Языки славянской культуры, 2004. 560 с.

16. Магировская О. В. Репрезентация субъекта познания в языке : автореф. дис. ... доктора филол. наук : 10.02.19; 10.02.04. Тамбов : ТГУ, 2009. $31 \mathrm{c.}$

17. Мартинюк А. П. Когнітивно-дискурсивний напрям дослідження концептів у сучасній лінгвістиці. Проблеми романо-германської філологї : зб. наук. пр. Ужгород, 2006. С. 92-107.

18. Маслова В. А. Введение в когнитивную лингвистику : учебное пособие. 2-е изд., испр. Москва : Флинта, 2006. 296 с.

19. Павиленис Р. И. Проблема смысла: современный логико-философский анализ языка. Москва : Мысль, 1983. 286 с.

20. Позднякова Е. М. Концептуальная организация производного слова. Когнитивная семантика : материалы 2-й междунар. школы-семинара по когнитивной лингвистике. Тамбов, 2000. Ч. 2. С. 23-27.

21. Полюжин М. М. Про синкретичні теорії концепту. Проблеми романо-германської філології : 3б. наук. праць. Ужгород, 2006. С. 5-21.

22. Радзієвська Т. В. Нариси з концептуального аналізу та лінгвістика тексту. Текст - соціум - культура - мовна особистість : монографія. Інститут мовознавства ім. О. О. Потебні НАН України. Львів : Інформ.-аналіт. агентство, 2010. $491 \mathrm{c}$.

23. Рахилина Е. В. О тенденциях в развитии когнитивной семантики. Серия литературы и языка. Москва : Известия АН, 2000. Т. 59 (3). С. 3-15.

24. Рузин И. Г. Возможности и пределы концептуального объяснения языковых фактов. Bопросы языкознания. 1996. № 5. С. 39-50.

25. Селіванова О. О. Сучасна лінгвістика: напрями та проблеми : підручник. Полтава : Довкілля-К, 2008. $712 \mathrm{c}$.

26. Степанов Ю. С. Методы и принципы современной лингвистики. Москва : Наука, 1975. 313 с.

27. Урысон Е. В. Языковая картина мира VS обиходные представления (модель восприятия в русском языке). Вопросы языкознания. 1998. № 2. С. 3-21.

28. Ченки А. Семантика в когнитивной лингвистике. Фундаментальные направления современной американской лингвистики. Москва, 1997. С. 340-369.

29. Яворська Г. М. Прескриптивна лінгвістика як дискурс: Мова. Культура. Влада. Київ : НАН України. Інститут мовознавства ім. О. О. Потебні, 2000. 288 с.

30. Geeraerts D. Methodology in cognitive linguistics. Cognitive linguistics: Current applications and future perspectives / Ed. by G. Kristiansen et al. Berlin; New York : Mouton de Gruyter, 2006. P. 21-49.

31. Fauconnier G. Methods and Generalizations. Cognitive Linguistics: Foundations, Scope and Methodology. Berlin : Mouton de Gruyter, 1999. P. 95-128.

32. Fillmore Ch. J. Frame semantics and the nature of language. Annals of the New Academy of Sciences : conference on the Origin and Development of Language and Speech. 1976. Vol. 280. P. 20-32.

33. Jackendoff R. Semantics and Cognition. $8^{\text {th }}$ ed. The MIT Press, 1999. $283 \mathrm{p}$

34. Lakoff G. Philosophy in the Flesh: The Embodied Mind and its Challenge to Western Thought / Ed. by M. Johnson. New York : Basic Book, 1999. 624 p.

35. Lakoff G., Johnson M. Metaphors We Live by. Chicago : University of Chicago Press, 2003. 191 p.

36. Langacker, R. Grammar and Conceptualization. Berlin ; New York : Mouton de Gruyter, 1999. 427 p.

37. Putnam H. The meaning of meaning. Mind, language and reality : philosophical papers II. Cambridge : Cambridge University Press, 1975. P. 215-271.

38. Rudzka-Ostyn B. Conceptualization and Mental Processing in Language / Ed. by R. A. Geiger, B. RudzkaOstyn. Berlin; New York, 1993. P. 488-530.

39. Sinha Ch. Language, culture and embodiment of spatial cognition : abstracts of the $6^{\text {th }}$ International cognitive linguistics conference, 10-16 July 1999. Stockholm, 1999. P. 36-39.

40. Talmy L. Toward a Cognitive Semantics. Cambridge (Mass). A Bradford Book, The MIT Press, 2000. Vol. 1 : Concept Structuring Systems. 565 p.

41. Taylor J-R. Linguistic Categorization: Prototypes in Linguistic Theory. $2^{\text {nd }}$ Edition. Oxford : Oxford University Press, $1995.312 \mathrm{p}$. 


\section{Слабоуз В. В., Нікітіна Н. П. ОСНОВНІ МЕТОДОЛОГІЧНІ ПРИНЦИПИ \\ КОГНІТИВНИХ ДОСЛІДЖЕНЬ У ВІТЧИЗНЯНОМУ МОВОЗНАВСТВІ}

У статті представлено матеріал про основні методологічні принципи когнітивних досліджень у вітчизняному загальному мовознавстві. Актуальність дослідження пояснюється тим, що когнітивна лінгвістика розглядається як нова парадигма наукового пізнання $i$, отже, характеризується різними теоретичними положеннями. Розвиток когнітивізму різниться і є доволі самостійним у нашій країні та за кордоном. Існує певна плутанина у визначенні філософсько-теоретичних основ багатьох лінгвістичних положень, отже, існує потреба у спрощеному та вільному тлумаченні досить складних понять когнітивної лінгвістики. Основна мета статті - систематизувати основні теоретикометодологічні принципи вітчизняної версії когнітивної лінгвістики, яка відрізняється від зарубіжних парадигм знань не лище з точки зору передумов і припущень, а й у предметних областях ії інтересів i підходів до поставлених завдань і способів їх вирімення, а також з'ясувати вісім основних принципів когнітивних досліджень у вітчизняному загальному мовознавстві й проаналізувати їх. До уваги читача представлено й обтрунтовано вісім основних методологічних засад когнітивних досліджень y вітчизняному загальному мовознавстві. Проаналізовані приниипи й методологічно важливі положення, що визначають сучасні когнітивні дослідження мови, допомагають зробити висновок, що вітчизняна когнітивна лінгвістика - це сформований напрям лінгвістичної думки, принципово відмінний від зарубіжних аналогів. Вітчизняна когнітивна лінгвістика посідає особливе місце в кониептуальному просторі когнітивної лінгвістики й когнітивної науки в цілому. Когнітивна лінгвістика успадковує надбання всіх лінгвістичних парадигм, ще існували до неї, розвиває разом з філософією та психологією проблеми зв'язку між мовою та мисленням, але розглядає їх у таких категоріях, як знання, різновиди мовних знань, мовні модуси представлення знань, процедури використання знань, ментальні структури.

Ключові слова: вітчизняне загальне мовознавство, когнітивна лінгвістика, когнітивні дослідження, когнітологія, когнітолог, методологічні принципи, парадигма наукових знань. 